\title{
Etika Kepemimpinan Politik Dalam Penyelenggaraan Pemerintahan Indonesia
}

\section{${ }^{1}$ Anang Setiawan ${ }^{2}$ Erinda Alfiani Fauzi}

${ }^{1}$ Magister Ilmu

Pemerintahan, Fakultas Ilmu

Sosial dan Politik, Universitas

Muhammadiyah Yohyakrta;

${ }^{2}$ Magister Ilmu Pemerintahan, Fakultas Ilmu Sosial dan

Politik, Universitas

Muhammadiyah Yohyakrta;

\section{Email:}

1erindaalfiani1996@gmail.com; 2ananggsetiawan2016@gmail.com

\section{Artikel Info:}

Diterima : 01 November 2019

Direvisi : 10 November 2019

Disetujui : 30 Desember 2019

\begin{abstract}
ABSTRAK
Dengan etika dan moralitas yang kuat maka diharapkan praktek korupsi di Indonesia akan menurun. Selain dengan etika dan moralitas yang kuat maka reformasi birokrasi juga menjadi salah satu cara untuk mengurangi korupsi dan membangun pelayanan dan penyelenggaraan pemerintah yang baik. Etika dalam politik atau penyelenggaraan pemerintah memang memiliki sebuah fungsi yang sangat penting dalam pelaksanaan reformasi birokrasi ini. Pembahasan ini tentang bagaimana etika, moral dan contoh korupsi di Indonesia saling berhubungan. Pentingnya etika dan moral sebagai pemimpin. Penelitian ini menggunakan metode studi literature dimana membandingkan beberapa studi sebelumnya sebagai teori nilai budaya yang sama seperti diskusi sosial yang dilakukan di penelitian sebelumnya. Dalam penelitian ditemukan beberapa kasus korupsi yang terjadi di Indonesia yang berkaitan dengan etika kepemimpinan politik. Perilaku korupsi memang dipengaruhi oleh banyak hal, namun pada penelitian ini fokus membahas tentang dimana etika dan moralitas yang mempengaruhi perilaku korupsi yang dilakukan oleh pemimpin di Indonesia.
\end{abstract}

Kata kunci: Korupsi; Etika; Reformasi Birokrasi

\section{ABSTRACT}

With strong ethics and morality, it is expected that corruption practices in Indonesia will decline. In addition to strong ethics and morality, bureaucratic reform is also one way to reduce corruption and build good service and governance. Ethics in politics or administration of government does have a very important function in implementing this bureaucratic reform. This discussion is about how ethics, morals and examples of corruption in Indonesia are interconnected. The importance of ethics and morals as leaders. This study uses a literature study method in which compared several previous studies as the same cultural value theory as social discussion conducted in previous studies. In the study found several cases of corruption that occurred in Indonesia that discussed the ethics of political leadership. Corruption behavior is indeed caused by many things, but in this study the focus is to discuss ethics and morality that influence corruption committed by leaders in Indonesia.

Keywords: Corruption; Ethic: Breucratic 


\section{PANDAHULUAN}

Indonesia merupakan Negara yang berjuang dalam melawan korupsi. Pemerintah merupakan salah satu unsur penting dan utama dalam penyelengaraan pelayanan kepada masyarakat. Tercapainya pelayanan yang baik dan efektif itu tergantung pada strategi apa yang akan dilakukan oleh pemerintah untuk mencapai tujuan Negara. Jika terjadi penyimpangan seperti korupsi, kolusi dan nepotisme terjadi maka kerugian besar akan ditanggung oleh masyarakat negara pada umumnya, mengingat salah satu tujuan membentuk pemerintah adalah untuk meningkat kesejahteraan masyarakat. Lebih penting dari itu bahwa keberadaan satu negara dalam hubungannya dengan negara lain, yaitu pengakuan suatu negara yang merdeka itu di dasarkan atas adanya pemerintahan yang berdaulat (Asfarosya, 2017).

Kemajuan suatu Negara sangat ditentukan oleh kemampuan dan keberhasilan dalam melaksanakan pembangunan. Keberhasilan pembangunan terutama ditentukan oleh factor sumber daya manusia yaitu manusia sebagai actor yang paling dominan. Indonesia merupakan salah satu Negara terkaya di Asia dilihat dari keanekaragaman kekayaan sumber daya alamnya. Tetapi ironisnya, jika dibandingkan dengan Negara lain dikawasan Asia bukanlah sebuah Negara yang kaya namun bahkan menjadi Negara yang miskin. Salah satu penyebabnya adalah rendahnya kualitas sumber daya manusia Indonesia yang tidak dikembangkan dengan maksimal. Kualitas ini menyangkut dari pada kualitas moral dan kepribadiannya. Rapuhnya moral dan rendahnya tingkat kejujuran dari aparat penyelenggara negar menyebabkan terjadi korupsi. Kristiawan (2016) menyebutkan bahwa dimana revolusi mental dan pendidikan karakter dapat menjadi suatu pemecahan masalah dalam masalah rapuhnya moral di Indonesia.

Korupsi adalah kejahatan White collar crime atau kejahatan yang mengacu pada kejahatan orang-orang terpandang atau orang yang memiliki kekuasaan dan kedudukan (Mahardika, 2019). Korupsi di Indonesia dewasa ini sudah merupakan patologi social yang sangat berbahaya yang mengancam semua aspek kehidupan bermasyrakat, berbangsa dan bernegara. Korupsi yang seperti ini terjadi dalam semua tingkatan pemerintahan, tidak hanya di pusat tetapi juga di daerah-daerah. Bahkan, sejak diberlakukannya otonomi daerah berdasarkan UU Nomor 22 Tahun 1999 tentang Pemerintahan Daerah di ta-hun 2001 telah terjadi kecenderungan korupsi di Pemerintahan Daerah yang semakin meningkat secara drastis oleh para birokrat atau pejabat yang melakukan pelayanan publik.

Korupsi birokrasi (bureaucratic corruption) sebagai suatu perilaku yang dirancang yang sesungguhnya merupakan suatu perilaku yang menyimpang dari norma-norma yang diharapkan yang sengaja dilakukan untuk mendapatkan imbalan material atau penghargaan lainnya selanjutnya korupsi birokrasi adalah sebuah pembengkokan hukum dan ketidakjujuran seorang birokrat dalam menjalankan amanah dari rakyat (Awaludin, 2016). Selanjutnya , Bentuk-bentuk korupsi birokrasi dalam pelayanan publik dapat diidentifikasi dari perilaku-perilaku seperti suap, penggelapan, penyalahgunaan wewenang, perolehan barang dan jasa yang dilakukan secara illegal dan ketidakpatuhan birokrat dalam melakukan tugas (Awaludin, 2016).

Maka dari itu pemerintahan yang bersih saat ini menjadi tujuan mendasar bagi kelangsungan hidup suatu negara dalam upaya mewujudkan reformasi birokrasi. Era liberalisasi ekonomi yang ditandai dengan tingkat kompetisi tinggi antar negara menuntut kesiapan sumber daya dan perangkat kelembagaan dan hukum yang mendukung pasar yang sehat. Karena itu pemberantasan korupsi menjadi keharusan jika suatu negara ingin survive dan diperhitungkan dalam politik intenasional. Pembahasan tentang faktor-faktor apa saja yang menyebabkan 
terjadinya korupsi birokrasi serta dampak-dampak korupsi terhadap Negara dan bagaimana etika dalam berpolitik dan bernegara menjadi sangat penting sebagai cara pencegahan praktek korupsi di Indonesia.

\section{METODE PENELITIAN}

Metode penelitian yang dipakai adalah dengan cara studi literatur. Studi literatur adalah studi teori dengan menggunakan teori nilai budaya yang sama seperti diskusi sosial yang dilakukan di penelitian sebelumnya (Sugiyono, 2012).

\section{TINJAUAN PUSTAKA}

\begin{tabular}{|c|c|c|c|}
\hline No & Judul Artikel & Metode Penelitian & Hasil Penelitian \\
\hline 1 & $\begin{array}{l}\text { Inovasi Kepemimpinan } \\
\text { Kepala Daerah (Studi } \\
\text { Kasus: Walikota } \\
\text { Surabaya Ir. Tri } \\
\text { Rismaharini, MT). }\end{array}$ & $\begin{array}{l}\text { Kualitatif dengan } \\
\text { pengumpulan data } \\
\text { melalui wawancara dan } \\
\text { studi pustaka. } \\
\text { Informan penelitian } \\
\text { menggunakan purposive } \\
\text { sampling. }\end{array}$ & $\begin{array}{l}\text { Faktor kunci dalam keberhasilan program } \\
\text { inovasi di Kota Surabaya adalah blusukan } \\
\text { yang dilakukan Walikota disertai dengan } \\
\text { sifat disiplin. Faktor penghambat adalah } \\
\text { tekanan politik serta keterbatasan SDM }\end{array}$ \\
\hline 2 & $\begin{array}{l}\text { Faktor Pemimpin dan } \\
\text { Kepemimpinan dalam } \\
\text { Tata Kelola } \\
\text { Pemerintahan di } \\
\text { Kabupaten Purwakarta } \\
\text { Periode Tahun 2008- } \\
2015\end{array}$ & $\begin{array}{l}\text { Kualitatif dengan } \\
\text { pengumpula data } \\
\text { melalui wawancara dan } \\
\text { observasi. Analisis data } \\
\text { dilakukan melalui tiga } \\
\text { tahapan yaitu reading } \\
\text { the transcript, } \\
\text { categorizing and } \\
\text { contextualizing }\end{array}$ & $\begin{array}{l}\text { Dedi lebih mempertontonkan sebagai sosok } \\
\text { pemimpin informal. Gaya memimpinnya } \\
\text { yang non-konvensional dengan } \\
\text { mengembangkan pola diplomasi seni } \\
\text { budaya menjadikan Bupati Purwakarta } \\
\text { mampu membawa angin segar bagi peta } \\
\text { perpolitikan Jawa Barat }\end{array}$ \\
\hline 3 & $\begin{array}{l}\text { Model Kepemimpinan } \\
\text { Politik Sunda dalam } \\
\text { Konteks Pendidikan } \\
\text { Politik }\end{array}$ & $\begin{array}{l}\text { Kualitatif dengan } \\
\text { pendekatan studi } \\
\text { kasus. Pengumpulan } \\
\text { data dilakukan dengan } \\
\text { wawancara, observasi, } \\
\text { dan studi dokumentasi }\end{array}$ & $\begin{array}{l}\text { Pola kepemimpinan Dedi Mulyadi } \\
\text { merupakan kepemimpinan } \\
\text { transformasional yang sedikit otoriter, } \\
\text { karena selain berhasil memotivasi masryakat } \\
\text { Purwakarta untuk kembali melestarikan } \\
\text { Budaya Sunda, Dedi Mulyadi juga sedikit } \\
\text { otoriter terkait kebijakan pembuatan } \\
\text { patung. }\end{array}$ \\
\hline 4 & $\begin{array}{l}\text { Kepemimpinan Kepala } \\
\text { Daerah (Studi Kasus } \\
\text { Walikota Surabaya, Tri } \\
\text { Rismaharini dalam } \\
\text { Perspektif Emotional } \\
\text { Intelligence) }\end{array}$ & $\begin{array}{l}\text { Kualitatif deskriptif } \\
\text { dengan pengumpulan } \\
\text { data melalui } \\
\text { wawancara, observasi, } \\
\text { dokumentasi, dan } \\
\text { materi audio visual } \\
\text { sebagai data sekunder. }\end{array}$ & $\begin{array}{l}\text { Walikota Surabaya unggul dalam hal } \\
\text { kecerdasan, kepercayaan diri, prestasi, } \\
\text { inisiatif, optimisme, dan pelayanan prima. } \\
\text { Namun lemah dalam pengendalian diri } \\
\text { karena ketidakmampuannya dalam } \\
\text { menahan emosi yang destruktif ketika } \\
\text { berada dalam tekanan dan menghadapi } \\
\text { permasalahan, karena seringkali meluapkan } \\
\text { kemarahan dengan emosi yang meldeak- } \\
\text { ledak kepada bawahannya yang melakukan } \\
\text { kesalahan. }\end{array}$ \\
\hline
\end{tabular}




\begin{tabular}{|c|c|c|c|}
\hline No & Judul Artikel & Metode Penelitian & Hasil Penelitian \\
\hline 5 & $\begin{array}{l}\text { Karakteristik } \\
\text { Bureaucratic } \\
\text { Entrepreneur pada } \\
\text { Walikota Surabaya }\end{array}$ & $\begin{array}{l}\text { Kualitatif dengan data } \\
\text { sekunder yang berasal } \\
\text { dari tiga buah transkrip } \\
\text { wawancara yang } \\
\text { dilakukan oleh tiga } \\
\text { stasiun TV (NET TV, } \\
\text { Metro TV, dan TV } \\
\text { One). Diolah } \\
\text { menggunakan metode } \\
\text { inductive content analysis. }\end{array}$ & $\begin{array}{l}\text { Tri Rismaharini dianggap memiliki } \\
\text { karakteristik bureaucratic entrepreneurs yang } \\
\text { terwujud dari prestasi-prestasi yang } \\
\text { diraihnya selama dua periode } \\
\text { kepemimpinannya di Kota Surabaya. } \\
\text { Peneliti menemukan empat dimensi } \\
\text { karakteristik seorang bureaucratic } \\
\text { entrepreneurs yang ada dalam diri Tri } \\
\text { Rismaharini, yaitu ketulusan, kejujuran, } \\
\text { inovatif, dan integritas. Keseluruhan } \\
\text { karakter yang ditemukan sangat terkait erat } \\
\text { dengan nuansa demokrasi di Indonesia yang } \\
\text { sangat kental dengan perilaku korupsi, } \\
\text { kolusi dan nepotisme (KKN). }\end{array}$ \\
\hline 6 & $\begin{array}{l}\text { Fenomena } \\
\text { Kepemimpinan } \\
\text { Fenomenal (The } \\
\text { Phenomenon of } \\
\text { Phenomenal } \\
\text { Leadership) }\end{array}$ & $\begin{array}{l}\text { Kualitatif dengan } \\
\text { pendekatan deskriptif. } \\
\text { Menggunakan data } \\
\text { sekunder dengan studi } \\
\text { pustaka dari buku, } \\
\text { jurnal, koran, dan } \\
\text { informasi lainnya. }\end{array}$ & $\begin{array}{l}\text { Hasil penelitian ini menunjukkan bahwa } \\
\text { Jokowi dan Emil mempunyai model } \\
\text { pendekatan yang sama yaitu gabungan } \\
\text { antara pendekatan Rasional-Empiris dan } \\
\text { Normatif-Reedukatif, sedangkan Risma } \\
\text { menggunakan model pendekatan Normatif- } \\
\text { Reedukatif danLingkungan-Adaptif. Untuk } \\
\text { model kepemimpinan, ketiganya menganut } \\
\text { gaya kepemimpinan transformasional, tetapi } \\
\text { Emil memadukannya dengan gaya } \\
\text { kepemimpinan karismatik. Meski ada } \\
\text { sedikit perbedaan, namun model } \\
\text { pendekatan dan gaya kepemimpinan } \\
\text { tersebut menjadikan ketiganya sebagai } \\
\text { pemimpin yang berhasil. }\end{array}$ \\
\hline
\end{tabular}

Sumber: Diolah Oleh Peneliti, 2019.

Penelitian tentang kepemimpinan kepala daerah merupakan hal yang menarik untuk dikaji, karena keberhasilan suatu daerah sangat bergantung pada kepemimpinan kepala daerahnya tersebut. Suatu daerah yang dipimpin oleh pemimpin yang memiliki jiwa kepemimpinan yang baik dan inovatif secara langsung dapat menjadikan daerah yang dipimpinnya menjadi berhasil. Menurut Tjiharjadi (2007) secara normatif, keberhasilan kepemimpinan akan sangat tergantung kepada tiga unsur yang meliputi syarat, watak, ciri, gaya, sifat, prinsip, teknik, asas, dan jenis kepemimpinan sebagai pedoman dalam penyelenggaraan kepemimpinan. Kepemimpinanakan berjalan efektif, disegani, dan memiliki derajat yang tinggi apabila seorang pemimpin memiliki tiga kelebihan, yakni kelebihan dalam bidang rasio/intelektual (pengetahuan tentang tujuan organisasi, asas-asas organisasi, cara memutar roda organisasi secara efisien, dan tercapainya tujuan organisasi secara maksimal), kelebihan dalam bidang rohani (keluhuran budi pekerti, ketinggian moralitas, dan kesederhanaan watak), dan kelebihan dalam bidang jasmani (badan/ fisik yang sehat dan memungkinan untuk menjadi contoh dalam prestasi sehari-hari).

Salah satu contoh pemimpin yang dapat dikatakan berhasil memajukan daerahnya berkat inovasi-inovasi yang dilakukan adalah Ridwan Kamil (Wali Kota Bandung), Didi Mulyadi 
(Walikota Purwakarta), dan Tri Rismaharini (Walikota Surabaya). Fenomena beberapa Kepala Daerah yang berhasil membawa nama daerahnya dikenal di seluruh pelosok negeri dengan berbagai kemajuan dan terobosannya ini membuat faktor kepemimpinan merekalah yang menjadi sorotan bagi publik. Peran kepala daerah (Walikota dan Bupati) sangat menentukan keberhasilan suatu daerah, seperti yang dikemukakan oleh Maichal (2015) dalam penelitiannya yang dilakukan dengan menganalisis wawancara (interview) yang dilakukan oleh Tri Rismaharini di tiga stasiun TV swasta (NET TV, Metro TV, dan TV One) bahwa keberhasilan Pemerintah Kota Surabaya tidak lepas dari peran dan kepemimpinan Tri Rismaharini yang menjabat sebagai Walikota Surabaya selama dua periode, yaitu 2010-2015 dan 2015-2020.

Tri Rismaharini dianggap memiliki karakteristik bureaucratic entrepreneurs yang terwujud dari prestasi-prestasi yang diraihnya selama dua periode kepemimpinannya di Kota Surabaya. Peneliti menemukan empat dimensi karakteristik seorang bureaucratic entrepreneur's yang ada dalam diri Tri Rismaharini, yaitu ketulusan, kejujuran, inovatif, dan integritas. Keseluruhan karakter yang ditemukan sangat terkait erat dengan nuansa demokrasi di Indonesia yang sangat kental dengan perilaku korupsi, kolusi dan nepotisme (KKN). Selama dua periode kepemimpinan Tri Rismaharini sebagai Walikota Surabaya, dalam melakukan perubahan menggunakan pendekatan gabungan antara model pendekatan Normatif-Reedukatif dan Lingkungan-Adaptif, dengan memberikan penjelasan kepada target perubahannya mengenai pentingnya perubahan tersebut dilakukan. Seabgai contoh, pada kasus penutupan lokalisasi Dolly yang notabene tidak pernah berani dilakukan oleh walikota-walikota sebelumnya, Risma terlebih dahulu menggunakan pendekatan kepada para PSK dan mucikari dengan memberi penjelasan bahwa kebijakan ini merupakan keputusan yang terbaik yang harus tetap dilaksanakan demi kepentingan semua orang. Risma juga memberikan bekal berupa keterampilan melalui pelatihan yang diberikan agar para PSK dan mucikari tersebut mempunyai bekal dalam menjalani profesi dan kehidupan yang baru nantinya. Berdasarkan uraian tersebut, maka Tri Rismaharini merupakan pemimpin dengan karakteristik transformasional karena selalu terjun langsung ke lokasi permasalahan yang sedang terjadi (Ramdhani, 2018).

Pemerintah Kota Surabaya di bawah kepemipinan Tri Rismaharini tentu mengalami berbagai hambatan, terlepas dari keberhasilannya melalui berbagai program inovasi yang telah diterapkan. Hambatan tersebut berupa tekanan politik yang kuat dalam kebijakan penutupan daerah lokalisasi Dolly, tekanan politik yang terjadi berupa penolakan yang berasal dari Wakil Walikota Surabaya sendiri, yaitu Wisnu Sakti yang juga merupakan Ketua PDI-P Surabaya dengan alasan merupakan sikap resmi PDI-P dalam melihat realitas sosial prostitusi di Dolly. Ketersediaan sumber daya manusia yang terbatas merupakan hambatan dalam kepemimpinan Tri Rismaharini, untuk mengelola Kota Surabaya yang sangat luas itu, tidak hanya ide atau gagasan yang inovatif, namun ketersediaan para pelaksana di lapangan (Fachrudin, Yuwono, 2017).

Penelitian Rahmi (2015) mengatakan bahwa dibalik keberhasilan yang telah diraih oleh Surabaya di bawah sosok kepemimpinan Tri Rismaharini, mnyimpan berbagai sifat kurang baik yang dimiliki oleh Walikota Surabaya ini. Meskipun unggul dalam hal kecerdasan, kepercayaan diri, prestasi, inisiatif, optimisme, dan pelayanan prima. Namun lemah dalam pengendalian diri karena ketidakmampuannya dalam menahan emosi yang destruktif ketika berada dalam tekanan dan menghadapi permasalahan, karena seringkali meluapkan kemarahan dengan emosi yang meldeak-ledak kepada bawahannya yang melakukan kesalahan. 


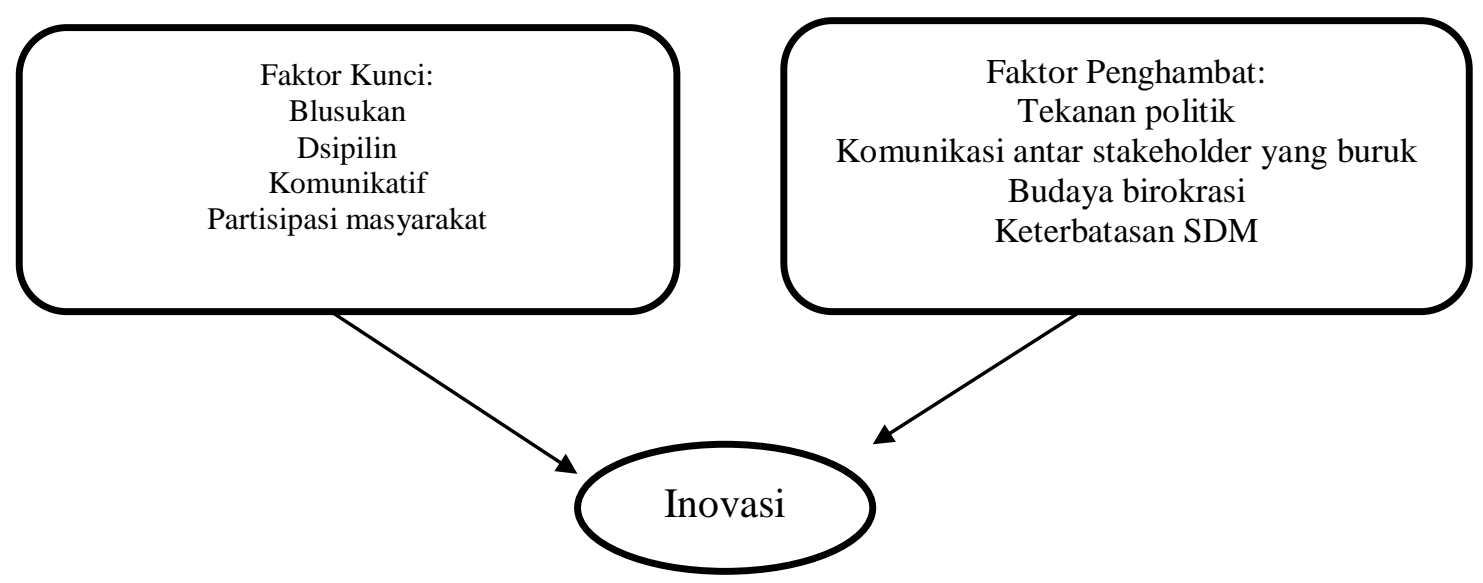

Sumber (Fachrudin, Yuwono, 2017).

Ketegasan dan kemarahannya bisa muncul kepada oknum birokrat tanpa melihat situasi dan kondisi. Tri Rismaharini sangat jarang untuk meminta maaf atas kesalahannya di depan orang yang telah ditergurnya dan dapat dikatakan bahwa beliau tidak ahli dalam menginspirasi bawahan, namun lebih tepatnya merupakan pemimpin yang mendireksi bawahan secara tegas.

Ramdhani (2018) mengemukakan bahwa karakteristik para kepala daerah di Indonesia berbeda-beda dan terbagi ke dalam beberapa pendeketan, yaitu pendekatan Rasional-Empiris, Normatif-Reedukatif, dan Lingkungan Adaptif. Pemerintah Kota Solo dalam melakukan perubahan di bawah kepemimpinan Jokowi saat itu menerapkan dua model pendekatan kepada warga kota Solo dengan menggabungkan pendekatan Rasional-Empiris dan pendekatan NormatifReedukatif. Dalam gabungan dua model pendekatan ini, Jokowi menerapkan teknik komunikasi yang informatif dan efektif agar warganya mau melakukan suatu perubahan. Jokowi terlebih dahulu banyak mendengar keluh kesah dari warganya mengenai apa saja keinginan mereka terkait kesejahteraan hidup dan kemajuan kota Solo. Setelah itu, Jokowi lantas membuat langkah-langkah strategis dalam melakukan reformasi birokrasi. Dalam memimpin Solo, gaya kepemimpinan yang digunakan oleh Jokowi adalah model kepemimpinan transformasional dimana ia melakukan rutinitas blusukan ke tempat-tempat yang memang memiliki tingkat urgensi yang tinggi dan memerlukan penanganan segera.

Terdapat kesamaan antara kepemimpinan Jokowi (Kota Solo) dan Ridwan Kamil (Kota Bandung) dalam hal pendeketan yang dilakukan kepada masyarakat terkait kebijakan yang akan dilakukan di daerahnya, yaitu dengan pendekatan Rasional-Empiris dan pendekatan NormatifReedukatif. Kota Bandung di bawah kepemimpinan Ridwan Kamil berkembang sangat cepat. Hal ini terjadi karena Ridwan Kamil sebagai Walikota menggunakan model pendekatan RasionalEmpiris dan pendekatan Normatif-Reedukatif. Teknik komunikasi yang baik menjadi modal penting bagi Ridwan Kamil dalam melakukan pendekatan kepada warganya untuk mau bersamasama melakukan perubahan demi mewujudkan kemajuan Kota Bandung. Media komunikasi seperti mediasosial layaknya facebook dan twitterpun menjadi pilihannya untuk berinteraksi dengan para pengikutnya. Ridwan Kamil tergolong pemimpin dengan paduan gaya kepemimpinan karismatik (charismatic leadership) karena sebelum menjabat sebagai Walikota Bandung dirinya 
sudah terkenal melalui berbagai prestasinya di bidang arsitektur dan aktivitas sosialnya sehingga masyrakat tidak ragu untuk memilihnya menjadi walikota, serta kepemimpinan transformasional (transformational leadership) karena selalu memotivasi warga Bandung agar berperan aktif dalam mewujudkan Bandung sebagai kota dengan masyrakat yang bahagia (Ramdhani, 2018).

Oleh karena itu, sama halnya seperti Jokowi dan Risma, Emil juga telah memiliki enam kualitas yang harus dimiliki sebagai seorang pemimpin menurut Pat Williams (dalam (Tjiharjadi, 2007)), yaitu visi yang jelas, keterampilan berkomunikasi, keterampilan bergaul, karakter yang baik, kompetensi yang baik, serta keberanian dalam ketegasan.

Pemimpin dengan gaya kepemimpinan yang baik dan inovatif lainnya berasal dari Kabupaten Purwakarta, yakni Dedi Mulyadi. Kabupaten Purwakarta merupakan salah satu daerah yang kental dengan nilai-nilai sunda. Dalam Masyarakat Sunda kepemimpinan tidak hanya bersumber dari proses resmi sebuah demokrasi dalam memilih pemimpin. Pemimpin yang sebenarnya diinginkan oleh Masyarakat Sunda adalah para pemimpin yang dipilih oleh rakyat dengan menampilkan nilai-nilai "kasundaan" yang bersumber dari filosofi Masyarakat Sunda (Sugara, Haddad, \& Hijran, 2017). Kemunculannya di panggung politik Jawa Barat, seperti fenomena tersendiri di mana dalam menjalankan roda pemerintahannya sebagai seorang bupati/kepala daerah, Dedi lebih mempertontonkan sebagai sosok pemimpin informal. Gaya memimpinnya yang non-konvensional dengan mengembangkan pola diplomasi seni budaya menjadikan Bupati Purwakarta mampu membawa angin segar bagi peta perpolitikan Jawa Barat. Pemimpin tidak harus rigid, kaku, formal dan konvensional. Hampir dua periode kepemimpinannya, Bupati Purwakarta mampu membuat berbagai macam terobosan kebijakan sehingga Purwakarta mengalami berbagai macam kemajuan. Tidak saja secara ekonomi melalui pembangunan fisik-material, tetapi juga secara kebudayaan melalui pembangunan spiritual immaterial (Febriantin, 2016)

Berdasarkan penelitian Haddad (2017) mengatakan Dedi Mulyadi berhasil mempengaruhi masyarakat Purwakarta untuk mewujudkan visi "Purwakarta Berkarakter" dengan melestarikan budaya kesundaan yang merupakan budaya leluhur masyarakat Purwakarta. Dedi Mulyadi menggabungkan pola atau gaya kepemimpinan tranformasional dengan gaya otoriter dalam memimpin Kabupaten Purwakarta. Pola kepemimpinan transformasional dilakukan oleh Dedi Mulyadi dalam sikap atau tindakan perilaku keseharian dengan selalu konsisten dengan gaya nyunda memakai pangsi dan iket. Ucapan Dedi Mulyadi mampu menginspirasi dan mempengaruhi untuk kembali menggunakan, menjaga dan melestarikan budaya Sunda dalam kehidupan sehari-hari dari mulai berpakaian hingga soal makanan. Sikap konsisten terhadap nilainilai kesundaan yang dicontohkan oleh Dedi Mulyadi kepada masyarakat Purwakarta membuat masyarakat termotivasi untuk menggunakan budaya Sunda dalam segala aspek kehidupan. Kepemimpinan otoriter yang terjadi adalah ketika kebijakan pendirian patung-patung yang ada di Purwakarta dibangun secara spontan tanpa ada sosialisasi terlebih dahulu kepada masyrakat.

\section{PEMBAHASAN}

Dalam bahasa Indonesia "Etika" berarti "kesusilaan" yang terdiri dari bahasa Sansekerta "Su" yang berarti baik, dan "Sila" yang berarti norma atau dasar kehidupan. Etika berkaitan dengan tingkah laku manusia untuk bertindak secara benar. Jadi etika selalu condong pada perbuatan baik. 
Secara etimologis etika berasal dari perkataan Yunani "Etos" yang berarti adat atau watak (Hulaimi, 2017). Kata ini identik dengan asal kata moral dari bahasa latin "Mos" (Jamaknya adalah Mores) yang juga berarti adat atau cara hidup (Sagala, 2018). Jadi kedua kata tersebut ( etika dan Moral) menunjukkan cara berbuat yang menjadi adat karena persetujuan atau praktek sekelompok manusia. Dengan demikian etika dapat di artikan sebagai suatu sikap kesediaan jiwa seseorang untuk senantiasa taat dan patuh kepada seperangkat peraturan-peraturan kesusilaan. Etika dan moralitas secara teoritis berawal dari pada ilmu pengetahuan (cognitive) bukan pada efektif. Moralitas berkaitan pula dengan jiwa dan semangat kelompok masyarakat. Moral terjadi bila dikaitkan dengan masyarakat, tidak ada moral bila tidak ada masyarakat dan seyogyanya tidak ada masyarakat tanpa moral, dan berkaitan dengan kesadaran kolektif dalam masyarakat.

Untuk mencari sistematika dalam etika pemerintahan sangat sulit karena pemerintahan selalu berubah menurut power yang berkuasa. Pegangan yang paling penting dalam etika pemerintahan ialah power dan authoritylotoritas kekuasan. Dalam hal pemerintahan kita memerlukan etika. Karena permasalahan pemerintahan menyangkut soal manusia. Ada dua unsur yang terlibat dalam soal pemerintahan:

a. Unsur yang memerintah di sebut pemerintah

b. Unsur yang di perintah di sebut rakyat

Dalam etika pemerintah harus ada partisipasi yang intensif dengan masyarakat. Harus di tanggapi segala keinginan-keinginan yang ada di masyarakat. Memang untuk menstimulir partisipasi ini memang sulit karena keinginan individu yang beraneka ragam. Dalam mengintensifkan partisipasi yang fleksibel bagi pemerintahan adalah penting. Sebab yang di perhatikan bukan yang memerintah tapi yang di perintah. Inti dari etika pemerintahan adalah penggunaan kekuasaan (The Use of power).

Secara umum fungsi etika pemerintahan dalam praktek penyelenggaraan pemerintahan ada dua:

a) Sebagai suatu pedoman, referensi, acuan, penuntun, dalam pelaksanaan tugas-tugas pemerintahan;

b) Sebagai acuan untuk menilai apakah keputusan dan/atau tindakan pejabat pemerintahan itu baik atau buruk, terpuji atau tercela.

Etika mempersoalkan baik dan buruk dan bukan benar dan salah tentang sikap, tindakan, dan perilaku manusia dalam berhubungan dengan sesamanya baik dalam masyarakat maupun organisasi public atau bisnis, maka etika mempunyai peran penting dalam praktek administrasi Negara. Etika diperlukan dalam administrasi Negara. Etika dapat dijadikan pedoman, referensi, petunjuk tentang apa yang harus dilakukan oleh administrasi negara dalam menjalankan kebijakan politik, dan sekaligus dapat digunakan sebagai standar penilaian apakah perilaku administrasi Negara dalam menjalankan kebijakan politik dapat dikatakan baik atau buruk. Karena administrasi Negara bukan saja berkait dengan masalah pelaksanaan kebijakan politik saja, tetapi juga berkait dengan masalah manusia dan kemanusiaan.

Di dalam implementasinya etika pemerintahan itu meliputi etika yang menyangkut individu sebagai anggota arganisasi pemerintahan, juga meliputi etika organisasi pemerintahan serta etika 
profesi organisasi pemerintahan, yang ketiganya dalam implementasinya bermuara pada nilai-nilai etis yang terkandung baik pada peraturan perundangan, nilai-nilai agama, nilai-nilai social budaya, nilai-nilai dalam asas penyelenggaraan pemerintahan dan nilai lainnya yang ada kaitannya dalam penyelenggaraan pemerintahan Negara

Isu tentang etika birokrasi di dalam pelayanan publik di Indonesia selama ini kurang dibahas secara luas dan tuntas sebagaimana terdapat di negara maju, meskipun telah disadari bahwa salah satu kelemahan dasar dalam pelayanan publik di Indonesia adalah masalah moralitas. Etika sering dilihat sebagai elemen yang kurang berkaitan dengan dunia pelayanan publik. Padahal, dalam literatur tentang pelayanan publik dan administrasi publik, etika merupakan salah satu elemen yang sangat menentukan kepuasan publik yang dilayani sekaligus keberhasilan organisasi di dalam melaksanakan pelayanan publik itu sendiri.

Elemen ini harus diperhatikan dalam setiap fase pelayanan publik, mulai dari penyusunan kebijakan pelayanan, desain struktur organisasi pelayanan, sampai pada manajemen pelayanan untuk mencapai tujuan akhir dari pelayanan tersebut. Dalam konteks ini, pusat perhatian ditujukan kepada aktor yang terlibat dalam setiap fase, termasuk kepentingan aktor-aktor tersebut apakah para aktor telah benar-benar mengutamakan kepentingan publik diatas kepentingankepentingan yang lain. Misalnya, dengan menggunakan nilai-nilai moral yang berlaku umum, seperti nilai kebenaran (truth), kebaikan (goodness), kebebasan (liberty), kesetaraan (equality), dan keadilan (justice), kita dapat menilai apakah para aktor tersebut jujur atau tidak dalam penyusunan kebijakan, adil atau tidak adil dalam menempatkan orang dalam unit dan jabatan yang tersedia, dan bohong atau tidak dalam melaporkan hasil manajemen pelayanan (Ismiyarto, 2016).

Sejalan dengan pesatnya perkembangan zaman dan semakin kompleksnya persoalan yang dihadapi oleh birokrasi, maka telah terjadi pula perkembangan di dalam penyelenggaraan fungsi pelayanan publik, yang ditandai dengan adanya pergeseran paradigma dari rule government yang lebih menekankan pada aspek peraturan perundang-undangan yang berlaku menjadi paradigma good governance yang tidak hanya berfokus pada kehendak atau kemauan pemerintah semata, tetapi melibatkan seluruh komponen bangsa, baik birokrasinya itu sendiri pihak swasta dan masyarakat (publik) secara keseluruhan.

Berbicara tentang pelayanan publik, masyarakat juga sudah mampu mengawasi pemerintah dalam penyelenggaraannya dengan memanfaatkan Teknologi, Informasi dan Komunikasi (TIK). Beberapa instansi pemerintahan telah menggunakan TIK dalam melakukan penyelenggaraan pemerintahan. Pemerintahan yang memanfaatkan TIK bisa juga disebut sebagai E-Government. EGovernment adalah Pelayanan public yang menggunakan teknologi informasi dan komunikasi atau dapat disebut dengan E-government yang bertujuan untuk meningkatkan kinerja pemerintah agar terus dapat memberikan informasi yang akurat dan transparan kepada masyarakat (Supriyanto, 2016). Dengan meningkatnya kinerja pemerintah maka diharapkan akuntabilitas dari aparatur pemerintah di sector publik meningkat. Akuntabilitas sendiri adalah sebuah hal yang sangat penting didalam pelayanan sector publik. Pelayanan pengadaan barang dan jasa dari pemerintah untuk rakyat harusnya dapat di pertangung jawabkan dengan baik dan benar. Akuntabilitas adalah kewajiban agen atau aparatur pemerintah untuk mengelola sumber daya, melaporkan, dan mengungkapkan segala aktivitas dan kegiatan yang berkaitan dengan penggunaan sumber daya publik kepada pemberi mandat (Eric Try Putra Benawan, David P.E Saerang, 2018). 
Dewasa ini, banyak sekali kasus-kasus muncul berkaitan dengan penyelewengan etika organisasi pemerintah. Salah satu contoh nyata yang masih saja dilakukan oleh individu dalam organisasi pemerintah yaitu KKN. Adapun definisi $\mathrm{KKN}$ yaitu suatu tindak penyalahgunaan kekayaan negara (dalam konsep modern), yang melayani kepentingan umum, untuk kepentingan pribadi atau perorangan. Akan tetapi praktek korupsi sendiri, seperti suap atau sogok, kerap ditemui di tengah masyarakat tanpa harus melibatkan hubungan negara. Praktek KKN (Korupsi, Kolusi dan Nepotisme) di Indonesia tergolong cukup tinggi. Contoh di bidang perbankan khususnya, keberadaan UU No. 10 Tahun 1998 ternyata tidak cukup ampuh menjerat atau membuat jera para pelaku KKN. Dari data yang ada, diketahui ada beberapa kasus yang cukup mencolok dengan nominal kerugian negara yang cukup besar.

Sebutlah kasus penyelewengan dana BLBI yang sampai saat ini sudah berlangsung hampir 10 tahun tidak selesai. Para tersangka pelakunya masih ada yang menghirup udara bebas, dan bahkan ada yang di vonis bebas dan masih leluasa menjalankan aktivitas bisnisnya. Yang lebih parah lagi, terungkap juga bukti penyuapan yang melibatkan salah satu pejabat Jampidsus beberapa waktu yang lalu. Praktek KKN dalam organisasi pemerintah khususnya, menjadi masalah berkaitan dengan etika organisasi pemerintah karena ini merupakan penyelewengan dari apa yang seharusnya dilakukan dan dimiliki oleh seorang individu dalam organisasi pemerintah, yakni melayani rakyat dengan baik dan berusaha memberikan yang terbaik bagi rakyat. Akan tetapi, dengan adanya praktek KKN jelas merugikan bangsa dan negara.

Selanjutnya, sebagai contoh Komisi Pemberantasan Korupsi (KPK) telah menetapkan Bupati Kotawaringin Timur, Kalimantan Tengah bernama Supian Hadi sebagai tersangka kasus dugaan suap terkait izin usaha pertambangan (IUP) di Kabupaten Kotawaringin Timur, Kalimantan Tengah. Izin itu dipersiapkan untuk tiga perusahaan berbeda.Atas penerbitan IUP itu KPK menduga Supian yang juga kader PDIP tersebut telah merugikan negara hingga Rp5,8 triliun dan US\$711 ribu (setara Rp9,9 miliar dengan asumsi kurs Rp14 ribu). Kerugian negara itu mengalahkan kerugian negara pada kasus korupsi e-KTP sebesar Rp2,3 triliun dan korupsi SKL BLBI sebesar Rp4,58 triliun. Hal ini berkaitan dengan etika dari pemimpin di Negara Indonesia yang tidak memiliki etika yang baik sehingga tidak bisa membedakan yang baik dan yang buruk.

Kasus korupsi yang terjadi dikalangan pemerintah dan pemimpin membuktikan bahwa dalam melaksanakan tugas mengemban mandate dari masyarakat harus memiliki moral yang baik dan etika yang benar. salah satu contoh kasus korupsi Gubernur Banten Ratu Atut Chosiyah divonis 5 tahun 6 bulan dan denda Rp 250 juta subsider 3 bulan kurungan. Ratu Atut terbukti melakukan tindakan korupsi dengan mengatur proses penganggaran pengadaan alkes Banten dan mengakibatkan kerugian negara sebesar Rp 79 miliar. Dalam pertimbangannya majelis hakim menyebut Atut terbukti memperkaya dirinya sebanyak Rp 3,8 miliar dan memperkaya adiknya Tubagus Chaeri Wardhana Rp 50 miliar. Dengan moral dan etika yang baik harusnya pemimpin kalangan pemerintah ini tidak melakukan korupsi, maka dengan etika yang baik maka korupsi itu bisa dikurangi bahkan dari dalam diri individu itu sendiri karena ada batasan salah atau benar.

Pemimpin dalam partai juga tidak luput dari perilaku korupsi. Tidak dapat dipastikan seseorang yang berasal dari partai berbasis agama Islam yang sudah jelas batasan salah dan benarnya semua dari mereka memiliki moral dan etika yang baik. Selain Romahurmuziy ketua partai PPP , KPK mengamankan HRS kepala kantor wilayah Kementerian Agama Provinsi Jawa 
Timur, MFQ kepala kantor Kemenag Kabupaten Gresik, ANY asisten dari RMY, AHB calon anggota DPRD Kabupaten Gresik dari PPP dan S supir dari MFQ dan AHB. Dalam operasi tersebut, tim KPK menyita uang sebesar Rp156.758.000. Uang tersebut, menurut Laode, hanya sebagian kecil dari pemberian-pemberian yang sebelumnya.

\section{KESIMPULAN}

Melakukan penyelenggaraan pemerintahan dan kebijakan publik pasti orang yang berkeja dan berperan didalamnya harus memakai etika, yaitu yang telah dijelaskan oleh Sagala (2018) adalah moral dan norma yang harusnya menjadi pegangan semua manusia tentunya orang yang melaksanakan tugas menjalankan kebijakan publik. Politik juga bukan semerta-merta tentang kekuasaan melaikan usaha untuk mencapai masyarakat yang lebih baik, maka dari itu dengan etika dan moral yang benar maka masyarakat yang lebih baik itu akan terwujud. Kebanyakan dari pelaku pengimplementasian kebijakan Publik adalah actor politik maka etika sangatlah penting.

Dengan etika dan moralitas yang kuat maka diharapkan praktek korupsi di Indonesia akan menurun. Selain dengan etika dan moralitas yang kuat maka reformasi birokrasi juga menjadi salah satu cara untuk mengurangi korupsi dan membangun pelayanan dan penyelenggaraan pemerintah yang baik. Etika dalam politik atau penyelenggaraan pemerintah memang memiliki sebuah fungsi yang sangat penting dalam pelaksanaan reformasi birokrasi ini. Menurut Kadir dan Junaidi (2018) Reformasi birokrasi adalah sebuah upaya dalam melakukan pembaharuan dan perubahan mendasar terhadap sistem penyelenggaraan pemerintahan terutama menyangkut aspekaspek kelembagaan (organisasi), proses pelaksanaan dan sumber daya manusia aparatur menjadi lebih baik. Untuk menjadikan sesuatu menjadi lebih baik maka memang etika sangat di perlukan untuk mendorong terlaksananya reformasi birokrasi. Secara ringkas, menurut The Liang Gie dalam Hestiyanto (2017) yang dijabarkan oleh Makmur mengatakan asas-asas pokok dalam sistem nilai atau etika administrasi modern harus memuat aspek tanggung jawab, aspek pengabdian, aspek kesetiaan, aspek persamaan dan aspek kepantasan. Fungsi dari etika politik itu secara tidak langsung sebagai pengawasan dan control terhadap reformasi tata kelola birokrasi terhadap setiap individu bila mengikuti dari aspek etika tersebut. Hal tersebut menjadi sangat efektif dalam mensukseskan reformasi birokrasi.

\section{DAFTAR PUSTAKA}

Abdul Kadir, J. (2018). Desain reformasi birokrasi melalui role model pelayanan publik berbasis smart pada pemerintahan kota bima (Studi pada Dinas Penanaman Modal dan Pelayanan Terpadu Satu Pintu (DPMPTSP) Kota Bima. Jurnal Administrasi Negara, 15(2), 1-13.

Asfarosya, N. (2017). Tinjauan yuridis mengenai hubungan diplomatik oleh negara dengan status kenegaraan yang masih dipertentangkan (studi kasus hubungan diplomatik taiwan dengan negara lain dan kaitannya dengan republik rakyat. Jom Fakultas Hukum, IV(April), 1-15.

Awaludin, A. (2016). Pandecta Ideologi Etis Penyingkap Korupsi Birokrasi. Jurnal Pandecta, 11(December), 189-201.

Fachrudin , Yuwono, T. (2017). Inovasi Kepemimpinan Kepala Daerah (Studi Kasus: Walikota Surabaya Ir. Tri Rismaharini, MT). Ournal of Politic and Government Studies, 6(2), 141-150.

Febriantin, K. (2016). Faktor Pemimpin Dan Kepemimpinan Dalam Tata Kelola Pemerintahan Di Kabupaten Purwakarta Periode Tahun 2008-2015. Jurnal Politikom Indonesiana, 1(2), 43-58. Retrieved 
https://journal.unsika.ac.id/index.php/politikomindonesiana/article/view/617

Hastiyanto, F. (2017). Etika dan Akuntabilitas Sektor Publik. Spirit Politik Volume, 12, 75-82.

Hulaimi, A. (2017). Etika bisnis islam dan dampaknya terhadap kesejahteraan pedagang. Jurnal Ekonomi Dan Bisnis Islam, 2(1), 17-31. Retrieved from http://journal.febi.uinib.ac.id/index.php/jebi/article/view/64/pdf

Ismiyarto. (2016). Etika dan penyelenggaraan pelayanan publik. Suara Khatulistiwa, 1-16.

Kristiawan, M. (2016). Telaah revolusi mental dan pendidikan karakter dalam pembentukkan sumber daya manusia indonesia yang pandai dan berakhlak mulia. Ta'dib, 18(1), 13-25. Https://doi.org/10.5772/46145

Mahardika, f. W. (2019). Pengadaan barang dan jasa secara elektronik di provinsi dki jakarta. Jurnal Hukum Adigama, 1(1), 1-25.

Maichal, C. B. U. (2015). Karakteristik Bureaucratic Entrepreneur pada Walikota Surabaya. Jurnal Enterpreneur Dan Enterpreneurship, 3(1), 13-24.

Rahmi, P. A. (2015). Kepemimpinan Kepala Daerah ( Studi Kasus Walikota Surabaya , Tri Rismaharini dalam Perspektif Emotional Intelligence ), 3(2), 112-121. Retrieved from http://journal.unair.ac.id/download-fullpapers-kmp2163504191full.pdf

Ramdhani, L. E. (2018). Fenomena kepemimpinan fenomenal (The Phenomenon of Phenomenal Leadership). Jurnal Borneo Administrator, 11(3), 268-297. Https://doi.org/10.24258/jba.v11i3.203

Sagala, H. S. (2018). Etika dan Moralitas Dalam Mengembangkan SDM Berbasis Sains dan Teknologi. In Seminar Nasional 21 Universitas PGRI Palembang 05 Mei 2018 (pp. 1-6).

Sugara, R., Haddad, M., \& Hijran, M. (2017). Model Kepemimpinan Politik Sunda dalam Konteks Pendidikan Politik. Prosiding Konferensi Nasional Kewarganegaraan III, (November), 326-337.

Tjiharjadi, S. (2007). To Be A Great Leader. Yogyakarta: CV. Andi offset. 